\title{
MENINGKATKAN HASIL BELAJAR MATEMATIKA MELALUI METODE BUZZ GROUP PADA SISWA KELAS VII 1 SMP NEGERI SATU ATAP BAHARI
}

\author{
Suwarni La Usa \\ Dosen Pendidikan Matematika FKIP Unidayan \\ annyie03@yahoo.co.id
}

\begin{abstract}
ABSTRAK
Tujuan penelitian ini adalah untuk meningkatkan hasil belajar matematika siswa kelas VII ${ }_{1}$ SMP Negeri Satu Atap Bahari melalui Metode Buzz Group. Penelitian ini adalah penelitian tindakan kelas dengan subyek penelitian siswa kelas VII $_{1}$ SMP Negeri Satu Atap Bahari yang berjumlah 21 orang. Desain pembelajaran dalam pokok bahasan segitiga dan segiempat dengan menggunakan metode buzz group yang telah disusun diberikan kepada siswa untuk dua siklus. Teknik pengumpulan data dalam penelitian ini meliputi (a) Observasi yaitu tentang aktivitas belajar siswa dan aktivitas guru, suasana pembelajaran di kelas ataupun observasi tentang lingkungan dan faktor-faktor yang mendukung ataupun menghambat keberhasilan pembelajaran pada materi segiempat dan segitiga dipergunakan untuk mengetahui peningkatan aktivitas siswa. (b) Tes hasil belajar siswa, tentang materi segiempat dan segitiga. (c) Jurnal harian yang berisi pernyataan atau komentar terhadap pembelajaran yang telah dilaksanakan juga saran untuk pembelajaran berikutnya. Hasil penelitian ini menunjukan bahwa ketuntasan belajar siswa siklus I adalah $66,67 \%$, siklus II adalah $85,71 \%$ artinya terdapat peningkatan prestasi belajar matematika siswa dengan kriteria tingkat keberhasilan tinggi. Dan juga diperoleh dari hasil observasi dapat meningkatkan aktivitas belajar siswa. Hal ini dapat dilihat dari persentase kegiatan siswa yang mengalami peningkatan setiap siklusnya.
\end{abstract}

Kata kunci: Metode Buzz Group, Hasil Belajar Matematika

\section{ABSTRACT}

The purpose of this research was to improve students' mathematics learning outcome at grade VII II $_{1}$ SMP Satu Atap Bahari through Buzz Group method. This research was classroom actions research with the research subject was students at grade $V_{I} I_{1}$ of SMP Satu Atap Bahari which consisted of 21 students. The learning design in learning topic of triangle and rectangle with using buzz group method which had made was given to the students for two cycles. The technique of data collection in this research included (a) Observation, that was about students' learning activities and teacher activity, learning atmosphere in the classroom or observation about environment and factors that supported or impeded the learning success on topic of rectangle and triangle were used to find out the increase of students' activities (b) Test of students learning outcome about topic of rectangle and triangle: (c) daily journal which contained statements or comments of the learning that had been done and also suggestions for next learning. The result of this research revealed that the students' learning completeness at cycle I was $66.67 \%$, at cycle II was $85.71 \%$. it meant that there is improvement of students' mathematics learning performance with the criteria of success level was high. This could be seen from the percentage of students' activities which improved at every cycle.

Keywords: buzz group method, mathematics learning outcome 


\section{PENDAHULUAN}

Perlu disadari bahwa pelajaran matematika pada umumnya kurang diminati oleh siswa. Hal ini mungkin saja disebabkan oleh penggunaan metode pembelajaran yang kurang tepat. Ketelitian dalam memilih dan menggunakan metode pembelajaran yang banyak melibatkan siswa secara aktif, dapat memberikan kesempatan bagi siswa untuk mengembangkan potensi yang dimiliki. Sehingga secara tidak langsung, berdampak pada peningkatan hasil belajar matematika siswa.

Banyak diantara guru yang telah mencoba metode pembelajaran yang mereka inginkan, namun karena kurang memahami dan menghayati apa yang dilakukan, maka mereka sering tergelincir ke metode pembelajaran tradisional yang otoriter (Pannen, 1999, p.271). Pembelajaran lebih berorientasi atau berpusat pada guru. Pembelajaran dilakukan dengan menggunakan kombinasi tiga metode mengajar yaitu ceramah, tanya jawab dan penugasan.

Pembelajaran dengan menggunakan kombinasi tiga metode mengajar tersebut tidak berjalan optimal, peserta didik hanya dijadikan sebagai subyek yang hanya mampu menerima informasi yang diberikan guru, mencatat dan sekali-kali bertanya sehingga peserta didik cenderung cepat bosan untuk mengikuti pembelajaran. Hal ini menyebabkan hasil belajar matematika siswa kelas $\mathrm{VII}_{1}$ masih tergolong rendah dimana setiap ulangan harian, ketuntasan belajar secara klasikal hanya mencapai $45 \%$. Ini

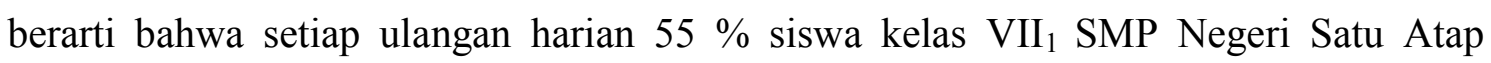
Bahari, semester ganjil tahun pelajaran 2014/2015 harus mengalami remedi. Ini merupakan suatu permasalahan yang perlu dicarikan solusinya. Karena itu, dalam penelitian ini dipilih metode pembelajaran Buuz Group untuk diterapkan dalam pembelajaran. Menurut Roestiyah (2001, p.9) Buzz Group adalah suatu kelompok besar yang dibagi menjadi 2 (dua) sampai 8 (delapan) kelompok yang lebih kecil sehingga jika diperlukan kelompok kecil ini diminta untuk melaporkan hasil diskusi yang mereka lakukan kepada kelompok besar. Senada dengan pendapat tersebut, menurut Hasibuan, dan Moedjiono (2004, p.20) Buzz group adalah suatu kelompok besar yang dibagi menjadi beberapa kelompok kecil, terdiri atas 4-5 orang. Tempat diatur agar siswa dapat berhadapan muka dan bertukar pikiran dengan mudah.Diskusi diadakan di tengah pelajaran atau di akhir pelajaran dengan maksud menajamkan kerangka bahan pelajaran, memperjelas bahan pelajaran atau menjawab pertanyaan-pertanyaan. 
Metode pembelajaran tersebut belum pernah diterapkan dalam pembelajaran matematika di kelas VII 1 SMP Negeri Satu Atap Bahari. Dengan demikian penerapan metode pembelajaran Buzz group diharapkan dapat meningkatkan hasil belajar matematika siswa kelas VII $\mathrm{VI}_{1}$ SM Negeri Satu Atap Bahari khususnya pada materi ajar "Segitiga dan Segiempat".

Hasil belajar matematika siswa akan meningkat apabila mereka ikut serta dalam aktivitas matematika, seperti mencoba membuat pengertian tentang metode dan membuat penjelasan yang mereka lihat atau dengar dari yang lain. Menurut Dubinsky dalam Usman (2001, p.306) menegaskan bahwa pengetahuan matematika bukanlah sesuatu yang dimiliki, melainkan suatu aktivitas yang dilakukan. Selanjutnya hasil belajar siswa dinyatakan dalam bentuk skor atau angka yang diperoleh dari hasil tes atau evaluasi (Arijo, 1987, p.125). Skor atau angka hasil belajar tersebut dapat diketahui setelah dilakukan penilaian di akhir setiap siklus penelitian tindakan kelas yang dimaksud.

\section{METODE PENELITIAN}

\section{Jenis Penelitian}

Penelitian ini menggunakan penelitian tindakan kelas (PTK). Karakteristik yang khas dari penelitian tindakan kelas yakni adanya tindakan-tindakan (aksi) tertentu untuk memperbaiki proses belajar-mengajar di kelas.

\section{Waktu dan Tempat Penelitian}

Penelitian ini dilakasanakan sejak tanggal 12 Januari 2015 sampai dengan 28 April 2015 di SMP Negeri Satu Atap Bahari.

\section{Subjek Penelitian}

Yang menjadi subyek dalam penelitian ini adalah siswa kelas $\mathrm{VII}_{1}$ SMP Negeri Satu Atap Bahari tahun pelajaran 2014/2015 sebanyak 21 siswa. Alasan pemilihan kelas $\mathrm{VII}_{1}$ sebagai subjek dalam penelitian ini adalah karena hasil belajar kelas ini lebih rendah dibanding kelas lainnya.

\section{Prosedur Penelitian}

Pelaksanaan penelitian tindakan kelas ini terdiri dari empat fase yakni perencanaan, pelaksanaan, observasi, dan refleksi. Tindakan yang digunakan dalam 
penelitian ini dengan menggunakan metode Buzz Group. Penelitian tindakan kelas ini dilaksanakan dalam dua siklus yang masing-masing siklus terdiri dari dua pertemuan untuk penyajian materi dan satu pertemuan untuk pemberian tes akhir siklus. Tiap pertemuan waktunya dua kali empat puluh menit.

\section{Data, Intrumen, dan Teknik Pengumpulan Data}

Jenis data yang diperoleh dalam penelitian ini adalah data kuantitatif dan data kualitatif. Data yang dikumpulkan adalah data hasil observasi keterlaksanaan metode Buzz Group dalam pembelajaran, tes hasil belajar matematika siswa dan catatan lapangan. Sumber data dalam penelitian ini adalah guru, peneliti dan siswa kelas $\mathrm{VII}_{1}$ SMP Negeri Satu Atap Bahari. Selanjutnya teknik pengumpulan data dilakukan dengan cara observasi dan tes.

\section{Teknik Analisis Data}

Pada penelitian tindakan kelas ini, teknik analisis data dilakukan secara deskriptif kualitatif. Data yang diperoleh selanjutnya dianalisis dengan menggunakan teknik analisis data yang dikembangkan Miles dan Huberman, yaitu pertama data reduction, kedua data display, ketiga conclution drawing and verification (Sugiono, 2005, p.91).

\section{HASIL PENELITIAN DAN PEMBAHASAN}

\section{Hasil Penelitian}

Hasil penelitian tindakan kelas siklus pertama dan siklus kedua adalah sebagai berikut:

Tabel 1

Hasil Belajar Siswa pada Tindakan Siklus I

\begin{tabular}{cccccccc}
\hline \multicolumn{2}{c}{ Tes Hasil Belajar } & \multicolumn{4}{c}{ Ketuntasan Hasil Belajar } \\
\hline Kategori & Nilai & Rata-rata & Kategori & Indikator & Jumlah & Persentase \\
\hline Terendah & 30 & \multirow{2}{*}{68,33} & & Tuntas & $\mathrm{N} \geq 65$ & 14 & $66,67 \%$ \\
\cline { 1 - 4 } & & & & Belum & $\mathrm{N}<65$ & 7 & $33,33 \%$ \\
\hline Tertinggi & 90 & & & & & & \\
\hline
\end{tabular}

Hasil belajar siswa pada siklus pertama mengalami peningkatan dibanding sebelum tindakan. Sebelum tindakan, ketuntasan belajar hanya mencapai $23,81 \%$, sedang setelah tindakan siklus pertama ketuntasan belajar meningkat menjadi $66,67 \%$. Hal ini berarti bahwa peserta didik yang mengalami remedi berkurang dari 76,19\% sebelum tindakan menjadi 33,33\% setelah tindakan siklus pertama. Sedang nilai hasil 
belajar yang dicapai siswa yaitu terendah 30, tertinggi 90 dan nilai rata-rata kelas 68,33. Hal ini bisa terjadi sebab tindakan guru dalam pembelajaran siklus pertama lebih banyak memberi kesempatan kepada siswa untuk belajar. Guru hanya bertindak sebagai fasilitator dan pembimbing belajar. Ini dilakukan sesuai dengan langkah-langkah pembelajaran dengan metode Buzz Group yang mengutamakan adanya kerja sama dalam kelompok dan antara kelompok untuk mencapai tujuan pembelajaran. Dalam hal ini, siswa tidak hanya dapat bekerja sama dan bertukar informasi dengan anggota dalam kelompoknya tetapi juga dengan kelompok lain. Demikian pula siswa selalu mengikuti langkah-langkah pembelajaran yang disarankan guru. Dengan demikian tindakan siklus pertama tidak lagi menjadikan siswa sebagai subyek yang hanya mampu menerima informasi yang diberikan guru, tetapi siswa telah menjadi pembelajar yang kritis dan kreatif sesuai kemampuan yang dimiliki.

Tabel 2

Hasil Belajar Siswa pada Tindakan Siklus II

\begin{tabular}{|c|c|c|c|c|c|c|}
\hline \multicolumn{3}{|c|}{ Tes Hasil Belajar } & \multicolumn{4}{|c|}{ Ketuntasan Hasil Belajar } \\
\hline Kategori & Nilai & Rata-rata & Kategori & Indikator & Jumlah & Persentase \\
\hline Terendah & 55 & \multirow{2}{*}{75,71} & Tuntas & $\mathrm{N} \geq 65$ & 18 & $85,71 \%$ \\
\hline Tertinggi & 95 & & Belum & $\mathrm{N}<65$ & 3 & $14,29 \%$ \\
\hline
\end{tabular}

Hasil belajar siswa pada siklus kedua mengalami peningkatan dari siklus pertama. Setelah tindakan siklus pertama, ketuntasan belajar mencapai 66,67\%, sedang setelah tindakan siklus kedua ketuntasan belajar meningkat menjadi 85,71\%. Hal ini berarti bahwa peserta didik yang mengalami remedi berkurang dari 33,33\% pada siklus pertama menjadi $14,29 \%$ pada siklus kedua.

Selanjutnya dampak dari pelaksanaan tindakan siklus kedua sebagai mana disebutkan dalam temuan penelitian di atas, di samping dilihat dari ketuntasan belajar siswa, dapat pula dilihat dari nilai yang dicapai siswa. Nilai yang diperoleh siswa setelah tindakan siklus kedua, yaitu nilai Sedang terendah 55, tertinggi 95 dan nilai ratarata kelas 75,71. Hal ini bisa terjadi sebab tindakan siklus kedua merupakan pengulangan dari tindakan siklus pertama, sehingga tindakan siklus kedua semakin membiasakan guru dalam melakukan pembelajaran dengan metode Buzz Group. Demkian pula dengan siswa semakin terbiasa dalam menjawab pertanyaan seputar materi prasyarat yang diajukan oleh guru sebagai apersepsi juga semakin terbiasa mengemukakan pendapat atau menanyakan materi yang belum dipahami kepada guru. 


\section{KESIMPULAN DAN SARAN}

\section{Kesimpulan}

Berdasarkan paparan di atas, maka dapat disimpulkan bahwa penerapan metode Buzz Group dapat meningkatkan hasil belajar matematika siswa kelas VII $_{1}$ Negeri Satu Atap Bahari pada pokok bahasan "Segitiga dan segiempat".

\section{Saran}

Berdasarkan kesimpulan penelitian di atas, maka dapat dikemukakan beberapa saran sebagai berikut. Pertama, hendaknya guru diharapkan dapat mengetahui, memahami dan menerapkan metode Buzz Group dalam upaya untuk meningkatkan hasil belajar matematika. Kedua, bagi siswa, agar senantiasa meningkatkan hasil belajar matematika dan rasa percaya diri dalam menyelesaikan persoalan yang dihadapi serta jangan takut menghasilkan sesuatu yang baru demi meningkatkan pemahaman dalam belajar. Ketiga, diharapkan para peneliti berikutnya dapat menjadikan hasil penelitian ini sebagai salah satu bahan rujukan untuk melakukan penelitian dengan kajian yang serumpun dengan penelitian ini.

\section{DAFTAR PUSTAKA}

Davies, I.K. (1987). Pengelolaan belajar. Jakarta: CV Rajawali.

Dimyati \& Moedjiono. (1992). Strategi belajar mengajar. Depdikbud Dirjen Dikti: Proyek Pembinaan Tenaga Kependidikan.

Hasan. (2010). Upaya meningkatkan hasil belajar ekonomi melalui strategi pembelajaran kooperatif student team achievement division (STAD) pada kelas X-4 SMA Negeri 4 Baubau. Jurnal Akademika, Vol. VII No. 3 September 2010. Baubau: Universitas Dayanu IKhsanuddin.

Hasibuan \& Moedjiono. (1995). Proses belajar mengajar. Bandung: PT Remaja Rosdakarya. Hudojo, H. (1988). Mengajar belajar matematika. Jakarta: $\mathrm{P}_{2}$ LPTK.

Muhtar, R. (2000). Penelitian tindakan kelas bagi guru. Kendari: FKIP UNHALU.

Nasution, S. (1995). Didaktik asas-asas mengajar. Jakarta: Bumi Aksara.

Roestiyah, N.K. (1989). Masalah-masalah ilmu keguruan. Jakarta: Bina Aksara.

Rusyan, T. dkk. (1994). Pendekatan dalam proses belajar mengajar. Bandung: Remaja Karya.

Soekamto, T. (1993). Belajar dan pembelajaran. Jakarta: Dirjen Dikti.

Sudjana, N. (1998). Dasar-dasar proses belajar mengajar. Bandung: Sinar Baru Algensindo.

Sugiono. (2005). Memahami penelitian kuantitatif. Bandung: Alfabeta.

Supriadi. (2006). Penerapan pembelajaran dengan metode buzz group untuk meningkatkan motivasi belajar siswa. Skripsi, tidak Dipublikasikan. Jember : FKIP UNEJ.

Suprijanto. (2007). Pendidikan orang dewasa dari teori hingga aplikasi. Jakarta: PT Bumi Aksara. 
Usman, H.B. (2001). Meningkatkan pemahaman mahasiswa tentang konsep limit fungsi satu variabel real melalui pembelajaran kooperatif (Jurnal Ilmu Pendidikan). Malang: Universitas Negeri Malang.

Usman, U. dkk. (1993). Upaya optimalisasi kegiatan belajar mengajar. Bandung: Remaja Rosdakarya.

Wilis, D.R. (1996). Teori-teori belajar. Bandung: Gelora Aksara Pratama.

Winkel, W. S. (1991). Psikologi pengajaran. Jakarta: Gramedia. 